\title{
PUTEVI I STRANPUTICE U RAZUMIJEVANJU VJERE
}

\section{SAŽETAK}

Biti u pravu uvijek $i$ u svemu je jedna od najjačih egoističkih osobina kod čovjeka. Mnogi ljudi ne mogu podnijeti da i neki drugi mogu biti u pravu, pa čak i onda kada je to ljudskoj logici neobično. Veoma zanimljiv je odnos na relaciji otac i sin, kako ga Kur'an, a.š., navodi između Ibrahima a. s., i njegovoga oca. Ta ljubav i pažnja prema roditelju od strane djeteta nikada ne smije biti prekinuta, kao ni taj emotivni odnos, bez obzira na eventualne nesuglasice $i$ nerazumijevanja.

Međutim, jedina nit koja se morala prekinuti, jeste nit na ideološkom planu, kada sin (Ibrahim, a. s.,) zadržava svoj čisti tevhid, monoteizam, dok otac (Azer) ostaje privržen politeizmu - širku. I pored toga što nisu "na istome pravcu", dijete uvijek ostaje u obavezi da ispunjava svoje dužnosti prema roditeljima:

"Po dunjalučkim pitanjima budi dobar prema njima". (Kur'an)

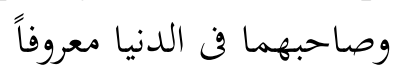

Drugi važan pogled na naslovljenu problematiku ukazuje na mogućnost ispravnih stavova dvaju (eventualno) suprotstavljenih strana, a obje mogu biti ispravne. (slučaj h. Omera, r. a. u tekstu)

Učenje je Kur'ana na različite načine bogatstvo u formalnoj različitosti, gdje je suština ostala ista. Nijanse ne smiju biti uzrokom međusobnoga sukobljavanja.

Pozivanje na Pravi put, put islama je prikazano kroz nekoliko primjera i na način koji nikako nije iz kolekcije mudrosti na koju Stvoritelj posebno ukazuje. Ponuđeni primjeri u tekstu ukazuju, nažalost, $i$ na jedan dio mladalačke populacije koja je puna isključivosti - nespremne da prihvati $i$ razumije duboku poruku Kur'ana i sunneta oko pitanja da'vetskog angažmana.

\footnotetext{
${ }^{1}$ Islamski pedagoški fakultet u Bihaću
} 
Čitaocu navedenog rada ostaje, da se i sam zapita koliko smo u društvenim i međusobnim odnosima spremni voditi razuman dijalog sa drugima ili drugačijima od nas.

Molimo Allaha, dž. š., da nam prosvijetli umove i ojača srca na putu Jedinog i Mudrog Allaha, dž.š. Amin!

Ključne riječi: Bid'at, islam, kur'anska i hadiska kazivanja, mevlud, odgovornost, Pravi put, radikalni stavovi, razumijevanje, vjera, zabluda.

\section{Uvod}

Vjerom se bave svi, kako oni koji je poznaju, tako i oni što misle da je poznaju. Ima, svakako, i onih koji su pošteno spremni kazati, da je to za njih nepoznanica, no mogu da slušaju.

Ukoliko prihvatimo ovu, uslovno načinjenu podjelu, vidjet ćemo da između dvije prve spomenute grupe postoji borba za pridobivanje treće spomenute grupacije. U takvome sukobu znalaca i kvaziznalaca, treći moraju biti dobro svjesni i duboko razumni da tumačenje pitanja vjere prihvate od onih koji su shvatljiviji i bliži ljudskome umu.

S obzirom da naslovljena tema traži ponudu sadržaja ispravnih puteva i stranputica, nastojali smo ukazati na problematiku u našem društvu općenito (među pripadnicima islama posebno), što to znači kada se ispravno znanje o islamu zamijeni sa ekstremnim i ličnim shvatanjem pojedinca.

Nažalost, nekada takvi pojedinci uspiju oformiti i manje grupe istomišljenika, čime odudaraju od sredine u kojoj žive. U nametanju svojih stavova nekada bi se i sila upotrijebila, ali je, hvala Allahu, dž. š., koji daje snagu razuma ljudima, pamet ta koja suzbija veće sukobe.

Uzvišeni Stvoritelj je stvorio čovjeka u najljepšem obliku, te ga uz to obdario čulima i razumom. Pored toga On je čovjeku slao i knjige uputa kao smjernice na putu Gospodara Jedinog, te ga tako osposobljenog učinio halifom (namjesnikom) na Zemlji. Tako pripremljen čovjek i može izvršiti svoju misiju na zemlji, ali ga Uzvišeni stavlja na razne kušnje, kako bi ih čovjek prepoznavao i savladavao. 
Dakle, sve pretpostavke za zanimljiv život na zemlji su postavljene, a mi se u njemu snalazimo onako, kako mislimo da je najispravnije i najbolje.

S obzirom da smo kao ljudska vrsta nesavršeni, u prilici smo da gore spomenute Božije blagodati prihvatamo i razumijevamo onoliko, koliko smo ispravno upotrijebili uputu, razum i čula.

Već je uobičajena fraza među ljudima, da svako sebe smatra boljim od drugoga i sposobnijim u rješavanju svjetske, kao i vjerske problematike. U jednome takvome razmišljanju je kazano, kako bi čovjek iz vreće punih raznih pameti najradije opet izvukao i prihvatio svoju.

U Kur'anu, a. š., nam Uzvišeni Gospodar kaže kako je stvorio čovjeka kao jedinku, zatim užu i širu ljudsku zajednicu, potrebu da budu upućeni jedni na druge: O ljudi, bojte se Gospodara svoga, koji vas od jednog čovjeka stvara, a od njega je i drugu njegovu stvorio $i$ od njih dvoje mnoge muškarce $i$ žene rasijao. I Allaha se bojte $-s$ imenom čijim jedni druge molite... (En-Nisa: 1, a slično i u suri ElHudžurat: 13)

I pored toga što formirane zajednice i društvo imaju određeni kodeks ponašanja i zakonodavstvo, pojedinci nezadovoljni ličnim statusom ili iz nekih drugih razloga, iskaču, te djeluju samostalno, ili formiraju nove manje grupe.

Zbog nezadovoljstva $\mathrm{u}$ radu osnovne vjerske grupacije, novonastale grupacije se radikaliziraju, želeći da poprave islamski umet. Moguće je, da te novoformirane male radikalne grupacije i budu u pravu kada ponekad primijete, da je šira zajednica u nekim pitanjima izašla iz okvira postavljenih od strane Vrhovnog Zakonodavca.

Međutim, nošeni željom za promjenama ili vraćanjem na stari kolosijek, prave krive poteze koji se protežu od nedovoljnoga šerijatskoga znanja, odnosno neznanja i nesposobnosti, do pogrešnog metoda, čak i onda kada im se čini da su za to osposobljeni. Na taj način dobivamo slučajeve koji se kasnije reflektiraju na cjelokupni islamski ummet.

Jedan je od takvih primjera neobičan slučaj u Kostajnici kod Konjica, gdje je pojedinac (pripadnik islama) ubio troje katolika. 
Ukoliko pažljivo analiziramo ovaj slučaj, moći ćemo vidjeti da su i drugi slučajevi nastali na sličnim elementima. Naime, sam počinitelj ovih ubistava je priznao svoje djelo i dao obrazloženje za njega. Izjavio je da se nešto mora uraditi, kako bi se teško stanje popravilo, te je ubistvima želio skrenuti pažnju na sebe i situaciju u državi. Na pitanje da li je kao vjernik-musliman znao da je ubio nevine ljude, te da je u Kur'anu rečeno da je ubistvo nevine osobe kao ubistvo cijelog čovječanstva, priznao je da je pogriješio i da se kaje.

Taj čovjek voli islam i svoju vjeru, ali je njegovo razumijevanje vjere u pogledu drugoga i drugačijega pogrešno, te je nasilnim putem mislio popraviti stanje. Ne treba zaboraviti da naš uzor Muhammed s.a.v.s. nije vratio istom mjerom Jevreju, koji mu je svako jutro obavljao nuždu pred vratima, nego ga je obišao kada se ovaj razbolio.

Islamsko učenje poziva na ozbiljnost muslimana vjernika $\mathrm{i}$ razmišljanje o odgovornosti, te da se posebno mora voditi računa o posljedicama svoga djelovanja. Nažalost, u spomenutom slučaju nije bilo takvoga razmišljanja. Posljedice toga čina su bile burne reakcije Hrvata širom svijeta, od Sjeverne Amerike do Australije, a pogotovo od hrvatske populacije u $\mathrm{BiH}$. Islamska zajednica, sa svojim službenicima, se pravdala da nema ništa sa spomenutim slučajem. Ista osoba je već ranije uhapšena u Srbiji s oružjem u pokušaju da taksijem dođe do tadašnjega predsjednika, Slobodana Miloševića i ubije ga. I jedan i drugi navedeni primjer ukazuje na to, da pogrešnim načinom razumijevanja vjere, čovjek može učiniti štetu i sebi i svojoj zajednici; naročito kada sebi daje za pravo da samostalno sudi, presuđuje i izvršava vlastite proizvoljne ideje.

\section{Vjera (ideologija) kao podloga za djelovanje}

Za izvršenje određenih poteza ljudi traže motivaciju, a kasnije i opravdanje, kroz ideologiju koja ga potiče na djelovanje.

Mnogi od nas se pitaju zašto nema izvinjenja od strane zločinaca i traženja oprosta za zlodjela, što su učinjena nad muslimanima BiH? Kako da se izvinjavaju zlikovci, kada ih je lično sveštenik poprskao svetom vodicom, blagosiljao i na taj način ga uputio da klanjem muslimana čini Bogu ugodno djelo. (Nažalost, imali smo prilika takve scene vidjeti u medijima.) Zašto tolike godine od izvršilaca 
genocida i zločina čekamo izvinjenje za ono što on smatra dobrim djelom!? Veoma važno bi bilo čuti odakle i kako ta sveštena lica pravoslavne crkve, kroje i daju odgovore na spomenuta ubistva.

Ni katolička crkva nije daleko otišla oko ovoga pitanja, jer su i njihovi pojedini svećenici slali ljude u borbu protiv muslimana, uz obećanje da će im oni (svećenici) oprostiti zla koja počine u ratu (Žitelji Domanovića kod Čapljine dobro pamte), te im je pored toga obećana zemlja i imovina ubijenih i protjeranih muslimana. Osim toga u proteklom ratu 1992 - 1995., kao i 1941-1945. godine, u Kiseljaku su ustaše pjevale pjesmu: Borimo se protiv krsta sa tri prsta, i protiv vjere što se pere.

Vrlo važno je i napomenuti da iza nasilja i zla ne može stajati jedna čista vjera kakav je islam, niti njeni zvanični službenici tj., zlo može biti proizvod samo izdvojenih pojedinaca. Nažalost, ovakva se konstatacija ne može reći i za druge dvije komšijske vjerske zajednice.

\section{Radikalni stavovi pojedinaca}

Na prostoru Balkana, pa time i Bosne i Hercegovine islam je došao preko Osmanlija, čime su naši preci, preko njih i mi, bili nosioci ehlisunnetskoga islama i hanefijskoga mezheba. Na taj se način vjekovima na našem prostoru učvršćivala vjera islam po principima izgrađenim na Kur'anu i sunnetu. Svakako da su i običaji pojedinih adžemija, novih nearapskih muslimana u nekim svojim dijelovima ostali zadržani u tradiciji, ali ni u kome slučaju nije dolazilo u pitanje akaidsko i čisto monoteističko islamsko učenje.

U eri razvoja i napretka u svim vidovima saobraćaja i komunikacija, a ona je u stalnome usponu, naši su prostori postali i poligoni za eksperimentisanje i primjenu nekih drugačijih islamskih pogleda na svijet. Sučeljavanjem sa drugačijim, nastajali su određeni problemi u razumijevanju vjere i njenih pitanja, te pokušaji da se neke pogrešne stvari isprave. U većini bi slučajeva to bilo sukobljavanje verbalne prirode, odnosno pisanom riječju, a ponekad, nažalost, fizičkim obračunima u dokazivanju ispravnosti svojih mišljenja.

Kulminacija nesporazuma šire zajednice i pojedinaca je nastala za vrijeme posljednjega rata $\mathrm{u} \mathrm{BiH}$, kao i u vremenu nakon njega. Pokušala se iskoristiti ta nesretna ratna situacija, kako bi se uticalo na 
promjene u svijesti i vjerovanju Bošnjaka-muslimana. Od bitnijih stavki na popisu pitanja koja treba rješavati su sljedeća:

\section{Zašto gradite džamije na grobovima - mezarima?}

Tačno je kako se vizuelno daju primijetiti, u neposrednoj blizini mnogih naših džamija, stari kaburovi. Međutim, džamije su još starije i sagrađivane su na čistoj površini, a zatim su, kod nekih od njih, mnogi zaslužni ljudi, autoriteti među muslimanima (vakifi, imami, muderrisi, mutevelije i sl.) nakon izgradnje džamija bili ukopavani u njenom dvorištu, te je tako nastajao i harem oko džamije, a ne džamija na grobovima. Vjerovatno bi $\mathrm{u}$ formi efdalijjeta bilo bolje ne ukopavati oko džamije, a mrtve velikodostojnike ukopavati u mezarja sa ostalim svijetom;

\section{Zašto koristite tespih u zikru poslije namaza?}

Ovo pitanje upućuje na nešto što je kao novotarija (bid'at) na našim prostorima, a jedan zanimljivi dijalog je tekao ovako:

- Možete li se vi osloboditi tespiha iz džamije?

- Možemo, ali to nije trajno rješenje. Npr., hajde da iz naše džamije izbacimo sve tespihe u Miljacku, neka ih voda odnese. No, te iste godine ili možda iduće ode naš džematlija na hadž (ili umru) $i$ kupi dosta tespiha za prijatelje $i$ za svoje džematlije, pa $i$ za svoju džamiju. Nakon toga mi ponovo pokupimo sve tespihe $i$ opet ih bacimo u rijeku Miljacku. I onda odu ljudi ponovo na hadž i kupe tespihe, i to na svetim mjestima Mekke i Medine, i donesu ih u svoju Bosnu i svoju džamiju. Dokle misliš da bi mogli tako raditi, sve dotle dok tih istih tespiha ne bude na najsvetijim mjestima muslimana.

Drugi veoma težak i zanimljiv slučaj radikalno-ekstremnih stavova pojedinaca je slučaj ubistva majke od muslimana-radikala. Naime, u Sarajevu je prije par godina momak ubio majku (zaklao je). U jednoj od verzija se kaže zato što nije htjela da ga sluša i pokrije se! Nije daleko od istine pretpostavka da je spomenuti ubica svoje majke bio indoktriniran ekstremnim učenjem, poput onoga što navodi Salahuddin al-Rozaji u svojim Artiklima. (Knjiga 1: 132) On kaže: (...) ako se desi da i poslije svih ovih pokušaja ta žena i dalje nastavi da se pojavljuje u javnosti otkrivenog lica, onda Emir može da naredi da se ona pogubi! 
Nažalost, izgleda da ubica majke nije bio upoznat sa kur'anskim ajetom u kome se zabranjuje svojim roditeljima reći i $U h:$ (...)i da roditeljima dobročinstvo činite. Kad jedno od njih dvoje, ili oboje, kod tebe starost dožive, ne reci im ni 'Uh', i ne podvikni na njih i obraćaj im se riječima poštovanja punim (El-Isra: 23), a nekamoli dići ruku na njih. U ovom je slučaju, kao što vidimo, došao do izražaja problem džehaleta (neznanja) oko pitanja dužnosti, prava i obaveza prema roditeljima. Također se može reći, da je i spomenuti mladić-ubica, žrtva koja je izašla iz ateističkoga društvenoga sistema u jedan nedovoljno definiran sistem ekstremnoga pristupa vjeri. Mnogi od ovakvih koji žele po svaku cijenu nešto promijeniti kao da zaboravljaju na ovu lekciju o roditeljima ili je svjesno izbjegavaju. I odgajatelj Muhammeda, a. s., Ebu-Talib nije bio ono što je Poslanik htio da bude, pa njegov život nije završen ubistvom - a on nam je najljepši uzor!

U svakome slučaju, nedovoljno poznavanje islamskog učenja je prouzrokovalo tu tragediju. Uzvišeni Allah kaže:

وكنلك جطناكم أمة وسطا Učinili smo vas ummetom sredine (ElBekara: 143) što znači da nema zastranjivanja bilo u desnu bilo u lijevu stranu, nego islamski princip umjerenosti i sredine.

U kontekstu napisanoga možemo spomenuti i kur'anski tekst, metodu Ibrahima, a. s., prema svome ocu-mušriku kojega mnogo voli i želi mu dobro. I pored toga što je otac zaglibio u širku, sinu Ibrahimu nije na um palo da digne ruku na njega. Naprotiv, on mu se obraća s toliko ljubavi, poštovanja i žalosti istovremeno:

(...) O babuka moj, zašto se klanjaš onome koji niti čuje, niti vidi, niti ti može od ikakve koristi biti?

O babuka moj, meni dolazi znanje, a ne tebi, zato mene slijedi $i$ ja ću te na pravi put uputiti.

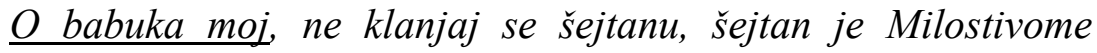
uvijek neposlušan.

O babuka moj__bojim se da te od Milostivoga ne stigne kazna, pa da budeš šejtanu drug. (Merjem: 42 - 45)

Nakon odbijanja oca da posluša tople riječi sina, Ibrahim, a. s., naziva selam ocu i kaže kako će se moliti Gospodaru za njega da mu 
oprosti. Pogledajmo još jednom arapski tekst: يا بت (O, babuka moj), a nije rekao يا بـ (O oče moj). Smatram vrlo važnim napomenuti da u komunikaciji djece kod Arapa ovakvo razumijevanje ima svoje utemeljenje, jer je bliskost i ljubav djeteta prema svome ocu daleko izraženija ako se kaže načinom kako je to rekao Ibrahim, a. s. Također, u Kur'anu i Jusuf, a. s., se sa puno nježnosti, na isti način obraća svome ocu Jakubu, a. s. U srcu Ibrahima, a. s., nema uopće mjesta za teške riječi ocu zbog odbijanja vjere, a ni blizu podizanja ruke ili glasa na svoga roditelja.

U nastavku dijaloga, u riječima Ibrahimovog, a. s., oca, nema uzvraćene topline u riječima. Naprotiv, on ga ne oslovljava riječima sine moj ili sinko moj, nego mu se obraća imenom Ibrahime (...) okani me se. Uz dozvolu Gospodara, Ibrahim, a. s., je činio i dalje dovu za svoga oca, do roka kojeg mu je On dopustio. No, nikada od Allaha dž. š., nije dobio naredbu, niti je sam od sebe ikada išta nažao učinio svome ocu; nakon što mu je postalo sasvim jasno da je otac ogrezao u grijehu.

Onima koji žele svoje bližnje, pa i druge pozivati u vjeru islam, mora biti poznat put, način i metoda Allahovih poslanika, a pogotovo put i način posljednjega, Muhammeda a. s. Uzvišeni Allah kaže: Samo Allahovom milošću ti si blag prema njima, a da si osoran i grub, razbjegli bi se iz tvoje blizine. Zato im praštaj i moli se da im bude oprošteno i dogovaraj se sa njima... (Ali- Imran: 159)

Dakle, osornost i grubost nikako ne može biti osobina uspješnoga daije. Sjetimo se mnogih teških iskustava Muhammeda a. s., npr., misije u Taifu, kada povrijeđen i kamenovan, umjesto proklinjanja mušrika, čini dovu Allahu dž.š., da im oprosti, jer oni ne znaju, te moli Allaha dž. š., da iz njihovoga potomstva učini narod odan Jedinom Allahu.

Problemi današnje ekstremno-radikalne grupacije su u tome što bi oni željeli sve odmah $i$ sada da je u tewhidu, bez širka i kufra. Zašto onda postoji Džehennem i kazna na onome svijetu ako ćemo mi tu kaznu još ovamo sprovoditi bez suđenja i vaganja dijela?!

Međutim, da'vetski poziv traži strpljenje i dugotrajan rad na polju predstavljanja ispravnoga islamskoga naučavanja. Islamski moral i edeb zahtijevaju uzornost u svakome pogledu i u svakoj 
situaciji, a bogatstvo kur'anskih ajeta i hadisa Allahovog Poslanika a. s., jeste neiscrpno vrelo za uspjeh u da'vetskoj misiji.

Ranije spomenuti autor Salahuddin al-Rozai javno iznosi mnogo diskutabilnih i ekstremnih stavova, kao što su:

- Glasanje i izbori su zabluda,

- Zabrana džamijskih 'veza' koje nastaju između momaka $i$ djevojaka,

- Nema mogućnosti da bude više ispravnih mišljenja (stavova) $u$ islamu.

Ebu-Muhammed (Sandžaklija) je napisao djelo, štampano u Plavu pod naslovom Može li se opravdati neznanjem u djelima velikog širka i jasnog kufra? U zanimljivostima onoga što stoji u ovome radu nabrojat ćemo sljedeće:

- Osoba izgovara šehadet, ali je mušrik, jer mu to ništa ne koristi, jer ne zna šta znači; (str. 13)

- Demokratija je najveći šejtan ovoga doba; (str. 33)

- Zato naša ulema kaže da je ovakve ljude (munafike) dozvoljeno ubiti, ako u tome ima šerijatske koristi za muslimane; (str. 76)

- Kako čovjek može nekoga smatrati muslimanom i opravdavati ga neznanjem u stvarima osnove vjere, kad je samo to neznanje zapravo-nevjerstvo; (str. 92).

- Ako su Fahd i njegov brat Abdullah istog porijekla $i$ iz istog plemena, šta je to problem da ti njega proglasiš nevjernikom; (str. 100)

- (...) neki od daija, a najveća fitna su studenti koji uče u Medini; (str. 105)

- Demokratija je širk, veliki širk (...); (str. 113)

- Zato kažemo za malo dijete kad se rodilo kod nevjernika: 'To je dijete isto nevjernik i za njega važe propisi kafira'; (str. 119 i 134)

- Ne može se biti u isto vrijeme musliman i demokrata; (str. 172)

- Islamska zajednica je stvarno odlučila da upropasti onaj (svoj) narod; (str. 196) 
- Nema opravdanja za ulazak u Parlamente (...) glasanje (...) donošenje zakona kufra (...); (str. 228)

- Nije dozvoljeno da se klanja za imamom koji poziva na glasanje; (str. 229)

- SDA, komunisti, nacionalisti, sekularisti, demokrate, svi čine veliki širk; (str. 235)

- Onaj ko voli ovu državu (BiH) onu tvorevinu koja se sastoji od vlade, njenih zakona i sistema, onda ja kažem da je on kafir; (str. 245)

- Čovjek koji je izgovorio šehadet $i$ čini ibadet Allahu, Jednom Jedinom, u mnogim stvarima, ali se nije odrekao tuđih zakonodavstava i još uvijek sudi drugim zakonom. Je li to musliman? Nije; (str. 355)

- Ko god bude mušrik - ne smije ući u Kabu. Ne smije Fahd ući unutra, ne smije njegov brat ući unutra, ne smije Gadafi ući, ne smije Abdullah iz Jordana, ne smije ni jedan mušrik ući unutra. (str. 396)

(Da li je uopće potrebno komentirati navedeno, ili je samo bolje reći: No coment!)

\section{Slijeđenje samo ashaba}

O ovoj podtemi možemo govoriti s više aspekata, iako u nekim radikalnim stvarima nema mjesta u zauzimanju različitih stavova. Kada se zauzme stav (bolje rečeno busija) i kaže: Slijedimo samo ashabe!, postavlja se pitanje: Koje ashabe slijediti u situaciji kada se $i$ oni u nekim pitanjima razilaze?!

Svima nam je poznato koliki značaj i ulogu ima Kur'an u životu muslimana, odnosno, nema ni govora o biti muslimana bez čvrste povezanosti sa Kur'anom. No, i u tako značajnom segmentu, bilo je različitih razumijevanja kiraeta Kur'ana, pa je čak Muhammed s.a.v.s. intervenisao među ashabima. U jednoj zanimljivoj priči, sahih kazivanju se kaže:

Omer ibn Hattab, r. a., priča:

Za života Allahovoga Poslanika, s.a.v.s., čuo sam Hišama ibn Hakima kako uči suru El-Furkan. Poslušao sam njegovo učenje $i$ primijetio da se razlikuje od onoga kako je mene Božiji Poslanik, 
s.a.v.s., naučio. Umalo ga još u toku namaza nisam zgrabio, ali sam se strpio dok nije predao selam, a onda sam ga stisnuo njegovim ogrtačem i upitao:

"Od koga si naučio ovu suru? "Naučio me je Božiji Poslanik, s.a.v.s.", rekao je. "Lažeš", rekoh mu. "Božiji Poslanik, s.a.v.s., je mene naučio toj suri drukčije nego što si ti sad učio!" Poveo sam ga nakon toga Božijem Poslaniku, s.a.v.s., kome sam rekao:

"Čuo sam ovoga kako uči suru El-Furkan drukčije nego što si ti mene podučio'. Božiji Poslanik, s.a.v.s., reče: 'Pusti ga! Uči Hišame (da čujem)!" Učio je pred njim isto onako kako sam ga i ja čuo da uči, a Allahov Poslanik, s.a.v.s., reče:

"Tako je objavljena!"

"Uči ti Omere!", reče nakon toga. Ja sam učio onako kako je mene podučio, pa Božiji Poslanik, s.a.v.s., reče:

"I tako je objavljena. Ovaj je Kur'an, doista, objavljen na sedam načina učenja pa učite kako vam je lakše!"

Danas u svijetu ima deset priznatih kiraeta Kur'ana koji ispunjavaju uslove, a oni opet svoje rivajete i vedžhove. Ima i onih koji su neispravni i oni se spominju, ali samo kako bi se ukazalo na to da postoje i pogrešni kiraeti (načini učenja Ku'ana). Islamska ulema se slaže u tome da bi kiraet bio ispravan mora ispuniti tri osnovna uvjeta:

1. Da je Kur'an učen tako za vrijeme Muhammeda, s.a.v.s;

2. Da je u skladu sa prvim mushafom - hazreti Osmana, r. a;

3. Da se slaže s pravilima arapskog jezika.

Ukoliko nedostaje bilo koji od ovih navedenih uvjeta, kiraet se naziva neispravnim i Kur'an se ne može tako učiti.

Zanimljivo je napomenuti i to kako je El-Wasiti, jedan od alima napisao knjigu الكنز في القراعات العشر (Riznica o deset kiraeta), te po njoj držao predavanja. Tako je jednom prilikom bio napadnut od nekih pojedinaca, jer su mislili da postoji samo sedam ispravnih kiraeta. Tada je Ibn-Tejmije lično u zaštitu uzeo El-Wasitija, kako je i navedeno u njegovom djelu Fetava Ibn-Tejmije u poglavlju o kiraetima. Usput ćemo spomenuti da je i imam El-Džezeri napisao svoje čuveno djelo o deset kiraeta, nazvavši ga: النشر فى القراعات العشر 
Kada na polju i disciplini deset kiraeta imamo bogatstvo u raznovrsnoj ispravnosti, kojega ćemo, onda, ashaba ili ashabe slijediti?! Naravno, mi sve ashabe volimo i cijenimo, ali ne smijemo sebi dozvoliti da favorizirajući neke od njih, isključujemo mogućnost ispravnoga djelovanje drugih.

Također, šta reći za arapski Magreb (Libiju, Tunis, Alžir, Maroko i Mauritaniju), gdje preovladava malikijski mezheb i gdje svi skoro obavljaju namaz spuštenih ruku. Ili, gdje svi prilikom učenja ajeta iz sure El-Fatiha umjesto: Maliki jeumiddin, uče: Meliki jeumiddin, ili u suri Ihlas: Kufuen ehad, umjesto: Kufuven ehad, itd. Smijemo li mi onda i njima reći kako to nije ispravno, pa da preuzmemo uloge u popravljanju miliona sljedbenika islama malikijskoga mezheba?!

Vrlo važno je napomenuti da postojeće razlike nisu suštinske nego formalne prirode, radi kojih muslimani ne bi smjeli trošiti $\mathrm{i}$ rasipati svoju energiju, te zauzimati stavove poput onih koji su navedeni u ovome podnaslovu.

\section{Bid'ati i odnos prema njima}

Nema sumnje da je svaki iskreni musliman svjestan, kako je njegova vjera islam ona koja ga vodi sreći i zadovoljstvu na oba svijeta. Većini pripadnika islama je poznat kur'anski ajet ili njegov sadržaj:

$$
\text { ومن ييتغ غير الاسلام ديناً فلن يقبل منه وهو في الأخرة من الخاسرين }
$$

A onaj ko želi neku drugu vjeru osim islama, neće mu biti primljena, $i$ on će na onome svijetu nastradati. (Ali-Imran: 85)

No, posmatrajući islamski ummet nakon četverice pravednih halifa, pa do današnjih dana, možemo uočiti i neke zabrinjavajuće stavove pojedinaca i grupa čije postupke treba analizirati i valorizirati.

Kod mnogih se pojavio i strah od mogućih neislamskih natruha, koje bi se mogle ubaciti $\mathrm{u}$ islam, te onda, reagujući poput odbrambenog mehanizma, odbijaju to i nazivaju ga bid'atom (novotarijom). U jednoj se takvoj opreznosti u pojedinim slučajevima zna otići i predaleko, da se (svjesno ili nesvjesno) prekorače granice 
nazivajući isto bid'atom, odnosno sve češće to biva ono što nije $u$ skladu s nečijim vlastitim viđenjima islama i Šerijata.

Da bismo mogli tačno razlučiti šta je to bid'a, potrebno je više osvijetliti ovaj pojam, s više aspekata i uglova od strane velikih islamskih autoriteta.

Jedinstven je stav cjelokupne uleme ehli sunneta, da je zabranjena bilo kakva vrsta bid'ata (novotarije) u islamu ukoliko ona i najmanje narušava sadržaje nama poznatih imanskih i islamskih šarta. $\mathrm{S}$ obzirom da je islam cjelokupan ljudski sistem života, moguće se susresti i sa novinama koje mogu biti ili u skladu ili u suprotnosti s islamskim pogledom na svijet.

Riječ bid'a u arapskome jeziku ima značenje za nešto što je novo tj., nešto što ranije nije bilo, ili čin koji neko uradi što nikad niko prije njega nije učinio ili izumio. U Kur'anu se govori kako su sljedbenici Isa, a. s., pojačali svoj ibadet na način, da su u želji da se što više približe Allahu, dž. š., prekoračili granicu:

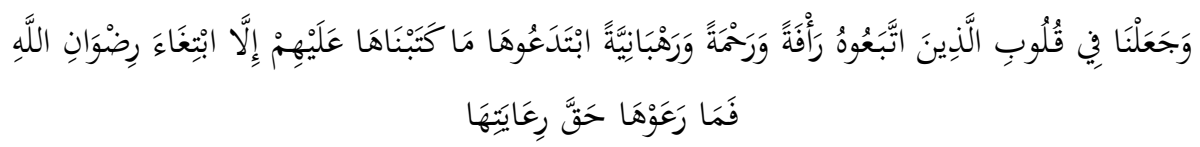

A u srca sljedbenika njegovih smo blagost $i$ samilost ulili, dok su monaštvo oni sami, kao novotariju, uveli. Mi ga nismo propisali, osim u želji da steknu Allahovo zadovoljstvo, ali oni o njemu ne vode brigu onako kako bi trebalo... (El-Hadid: 27)

$\mathrm{Na}$ osnovu ovoga kur'anskog teksta, riječ bid'a je navedena u pozitivnom značenju, iako oni $\mathrm{u}$ isto vrijeme dobivaju kritiku zbog toga što ne vode računa o svome pojačanom ibadetu.

Imam Šafija kaže da se bid'a dijeli na pohvaljenu i pokuđenu. Ona koja je u skladu sa sunnetom Božijeg Poslanika, s.a.v.s., jeste pohvaljena, a ona koja je u suprotnosti je pokuđena. ${ }^{2}$

Primjer bid'e, u pozitivnome značenju, jeste i onaj kada je hazreti Omer za vrijeme teravih-namaza u velikome džemaatu rekao: Divna li je ovo bid'a. ${ }^{3}$

\footnotetext{
${ }^{2}$ Fethul-Bari, 17/10.

${ }^{3}$ Buhari, Poglavlje o teraviji, 1.
} 
Imam El-Gazali također kaže, da je zabranjena svaka bid'a koja je u suprotnosti sa Kur'anom i sunnetom tj., Šerijatom, dok su neke novotarije proizvod i zahtjev vremena i potrebe ljudi. ${ }^{4}$ On u svome Ihjau navodi i neke stroge čuvare od bid'e koji u njegovo vrijeme nisu htjeli da ulaze i klanjaju u džamiji, ukoliko je ona bila pokrivena bilo čime osim hasurom. Šta bi tek sada rekli za raznolike ćilime i tepihe po našim džamijama, za lampu, sijalice i pozlaćene lustere, za struju od koje sija sva džamija?!

Ibn-Redžeb el-Hanbeli kaže, da je bid'a sve novo što nema nikakvoga utemeljenja u Šerijatu, a želi se njemu pripisati, dok novotarije koje nemaju ni utemeljenja, ni veze sa Šerijatom i nisu novotarije, makar to jezički i bilo isto. ${ }^{5}$

Ibn-Hadžer kaže, da je bid'a nešto novo što nije bilo ranije. Kada se spominje u domenu Šerijata, onda je ona pokuđena. ${ }^{6}$

U tekstovima hadisa Allahovog Poslanika, s.a.v.s., riječ bid'a je navedena uvijek u negativnom kontekstu, dok su hazreti Omer, EbuUmame i Abdullah ibn Omer iznijeli i mogućnost pozitivnog poimanja iste.

Savremeni alim i veliki svjetski autoritet danas, šejh ElKaradavi, je jednom prilikom bio upitan: $D a$ li je slikanje $i$ fotografisanje (تصوير) haram, tj. novotarija? Odgovor šejha je bio veoma neobičan: Dok nam Izraelci, uz pomoć Amerikanaca, snimaju $i$ slikaju svaki pedalj zemlje Arapa i muslimana, mi se bavimo takvim pitanjima!, želeći reći da je bavljenje i ovladavanje naučnim tehničkim dostignućima obaveza, a ne zabrana.

\section{Obilježavanje Mevluda Muhammeda s. a. v. s.}

Islamska ulema se slaže kako je svečano obilježavanje rođenja (Mevluda) našega Poslanika, s.a.v.s., nešto novo i da toga nije bilo u njegovo vrijeme, pa čak ni u prva tri stoljeća islama. Međutim, islamska ulema se razilazi kada se o ovome govori, pa jedni to nazivaju pokuđenom bid'om, a drugi pohvalnom bid'om.

\footnotetext{
${ }^{4}$ El-Gazali, El-Ihja, 2., str, 3.

${ }^{5}$ Ibn-Redžeb, Džamiul-ulum..., str. 160.

${ }^{6}$ Ibn-Hadžer, Fethul-Bari..., 5., str. 156. 
Glavni argumenti onih koji se protive mevludskim svečanostima jesu, da takvo nešto nije bilo u doba Poslanika, a. s., ashaba, niti tabiina. U prilog svojoj tvrdnji ubrajaju i rasipanje imetka (hrane) koja se tada koristi, zatim moguću upotreba muzike i miješanja muškaraca i žena.

Argumenti onih koji dopuštaju mevludske svečanosti su zasnovani na tome, da ne postoji nikakva šerijatska striktna zabrana (tekstom Kur'ana i hadisa) za takvo nešto, dok upotrebom analogije nalaze dozvolu za te činove.

Ibn-Hadžer kaže, da mevlud u sebi može sadržavati i pozitivne i negativne stvari, pa ko se trudi i nastoji to provesti na vjerski ispravan način, onda je to dozvoljeno, a ako se tom prilikom upražnjavaju zabranjene stvari, onda je i sam mevlud zabranjen. Dokaz za dozvoljenu novotariju je uzeo iz primjera Muhammeda, s.a.v.s., kada je vidio kako Jevreji Medine poštuju i slave Musa, a. s., i poste ašuru, te je rekao: Mi smo preči Musau od Jevreja, pa postimo i mi ašuru. Na taj je način iskazao poštovanje prema svome prethodniku i odobrio da je i muslimani poste.

U dozvoljene sadržaje svečanosti mevluda, ulema ubraja sljedeće: iskazivanje zahvale Allahu, dž.š., učenje Kur'ana, hranjenje siromašnih, dijeljenje dijela imetka, davanje sadake, učenje i citiranje pobožnih pjesama, poticanje ljudskih srca na dobro i sjećanje na Ahiret. $U$ isto vrijeme to ne treba da bude na štetu farz obaveza, misleći da smo time riješili svoje osnovne dužnosti prema Stvoritelju, niti da se u slavlju pretjeruje kroz fizički ili psihički umor. Ako je u pitanju svečanost kojom će se prikazivati golotinja, igra i zabava, nedozvoljene pjesme i sadržaji, onda to ulema kategorički zabranjuje. ${ }^{8}$

$\mathrm{Na}$ prostoru $\mathrm{BiH}$ mevludi su imali značajnu ulogu u očuvanju islama, spominjanju islamskih svetinja, Uzvišenoga Gospodara, Poslanika, s.a.v.s., Kur'ana itd. O tome se još uvijek može govoriti, ali samo u želji da ovakve svečanosti imaju cilj pojašnjenje i širenje islamskoga učenja - a Allah najbolje zna.

Ovim bismo izlaganjem zaokružili još jedan od pogleda na ekstremno-radikalan stav u pitanjima islamskoga učenja. Za neke od

\footnotetext{
${ }^{7}$ Ibn-Hadžer, Fethul-Bari, 3., str. 39.

${ }^{8}$ Dr. Izet Atijje, Bid'a, str. 417.
} 
njih smo ponudili kraći komentar, a neke nije bilo potrebno ni komentirati. Vaga tačnoga mjerenja se nalazi u Knjizi Uzvišenoga i najispravnijoj praksi Allahovog Poslanika, Muhammeda, s.a.v.s.

Molim Svevišnjega Gospodara da nam prosvijetli umove, i da nam pomogne na putu najispravnije primjene Njegovoga Šerijata za spas i sreću na oba svijeta. Amin!

\section{Zaključak}

Moguće je čovjeku osjetiti i nelagodu kada čita pojedine dijelove ovoga rada, ali se moramo suočiti sa stvarnošću i vremenom u kojem se nalazimo.

Zapitamo li se ponekad koliko mi doprinosimo pravoj ili krivoj slici islama u očima drugih?! Je li naša interpretacija vjere koju živimo potpuno u skladu s osnovnim islamskim načelima ili možda ponekad i sami sudjelujemo u pravljenju loše slike o sebi samima ili zajednici kojoj pripadamo?!

Navedenim tekstom smo se željeli još malo osvrnuti na naslovljenu problematiku i tematiku koja je danas skoro nezaobilazna. Razlog više leži u tome, što sve više imamo pismenijih i pametnijih junoša koji bi svojim istupima i nastupima davali sud o svemu, ne mareći ni jedan tren kakve sve posljedice mogu biti izazvane.

Intencijsko pravilo, pretečeno i u mudru poslovicu: Gledaj djelu posljedica, treba biti na umu svakome pojedincu u njegovim svakodnevnim djelatnostima, a kada su ozbiljnija i krupnija pitanja po srijedi, onda tu naročito treba imati mudrosti i odmjerenosti - gledati $u$ posljedice svoga čina.

Gospodaru naš, ukaži nam Istinu istinitom, daj da je slijedimo, $i$ pokaži nam laž lažljivom i ne daj nam da idemo za njom. Amin!

\section{Literatura:}

1. Atijje Izzet, El-Bid'a, Darul-kitab el-Arebi, Bejrut, 1980.

2. El-Askalani Ibn-Hadžer, Fethul-Bari, Darur-rejjan lit-turas, Kairo, 1987.

3. El-Gazali, Ebu-Hamid, Ihja'u ulumid-din, Bookline, Sarajevo, 2007. 
4. El-Hanbeli Ibn-Redžeb, Dažmi'ul-ulumi vel-hikem, Muesseseur-risala, Bejrut, 1995.

5. Hadiske zbirke

6. Kur'an, a.s.

7. Sandžaki Ebu-Muhammed, Može li se opravdati neznanjem u djelima velikog širka i jasnog kufra?, Plav, 2002. 
DOC. DR. IZET TERZIĆ, SENIOR LECTURER

\section{ROADS AND MEANDERINGS IN UNDERSTANDING OF FAITH}

\section{SUMMARY}

The quality of having right always and in every situation is one of the strongest egoistical qualities of a human. Many people cannot bear that others can be right, even when it is unusual to human logic.

Relationship which Qur'an mentions between a father and a son - Abraham, peace be upon him, and his father is very interesting. Love and devotion towards parent from his child must never be broken, nor that emotional relationship, regardless of disagreements and misunderstandings. However, only thread that had to be broken was on the ideological level, when son - Abraham, peace be upon him, keeps his pure monotheism, while father - Azer stays devoted to polytheism, meaning shirk. Despite not being on the same ideological direction, child is always required to fulfil his duties towards his parents:

Second important view on addressed problems indicates a possibility of correct views of two opposing sides, and both of them can be correct (see example of Omar, Allah be pleased with him, which is stated in the text).

Recitation of the Qur'an in various ways represents a wealth in formal differences where the essence remains identical. Nuances must not be the cause of the mutual conflict.

Calling to the Right path, path of Islam is described through several examples and in a way not found in the collection of wisdom which is particularly indicated by the Creator. Provided examples in the text unfortunately indicate to one part of youthful population which is full of exclusivity, and not prepared to accept and understand deep message of the Qur'an and the Sunnah regarding missionary engagement.

It is left to the reader of the above work to ask himself how much we are willing to conduct a rational dialogue with other people or people different from us, in our social and mutual relationships. 
Key words: narrations from the Holy Qur'an and the Sunnah, religion, Islam, the Right path, understanding, responsibility, mewlud, bid'at, delusion and radical opinions. 
الأستاذ المساعد د. عزت ترزيتش

\section{الطرق والانحرافات في فهم الدين}

\section{خلاصة البحث}

يعتبر الاعتقاد بأن الشخص على حق في كل شيء واحداً من أقوى سمات الأنانية في البشر. كثير من الناس لا يمكنهم أن يتحملوا كون البعض الآخر على حق، حتى عندما يكون ذلك غير مألوف للمنطق البشري.

من المثير جداً للاهتمام العلاقة بين الأب والابن، كما يحكيها القرآن الكريم بين إبراهيم وأبيه. ذلك الحب وتلك الرعاية من الطفل تحاه الوالد لا يجب أن تنقطع أبداً، كما هو الحال بالنسبة للعلاقة العاطفية، بغض النظر عن خلافات مفترضة أوسوء التفاهم. ولكن الخيط الوحيد الذي اضطر إلى قطعه هو الخيط الأيديولوجي، عندما يتمسك ابنه إبراهيم، عليه السلام، بتوحيده

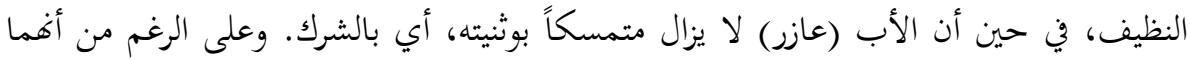
ليسا "في الاتحاه نفسه"، فإن الولد يبقى في إطار الالتزام بواجباته بحاه والديه: "وَصَاحِبْهُهمَا فِي

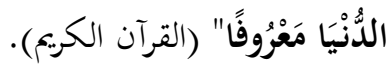

وثمة نظرة أخرى هامة في القضية المذكورة تشير إلى احتمال الصواب لدى الطرفين المتنازعين، وأن كليهما قد يكونان على حق (مثال سيدنا عمر رضي الله عنه في النص).

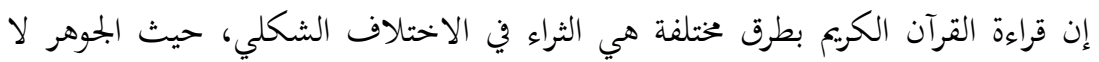
يزال على حاله. الفروق البسيطة لا ينبغي أن تكون سبباً للمواجهة.

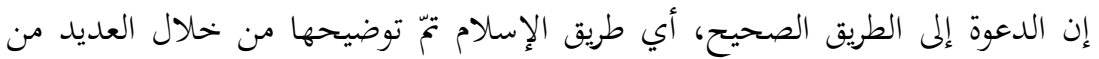
الأمثلة وبطريقة لا تمكن أن نصنفها من جملة الحكم التي يشير إليها الخالق بشكل خاص. لإ. الأمثلة

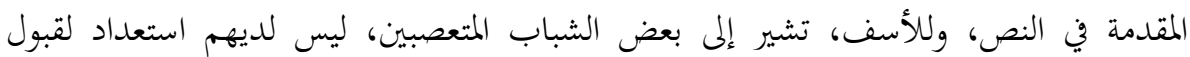
وتفهم عمق رسالة القرآن والسنة بشأن الدعوة.

إن القارئ للبحث هذا له أن يتساءل شخصياً إلى أي مدى نحن نهن على استعداد للقيام

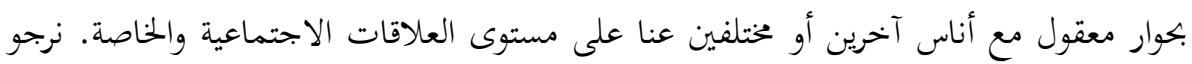
الله سبحانه وتعالى أن ينوّر عقولنا ويقوّي قلوبنا في سبيل الله الوحيد الحكيم. آمين. 


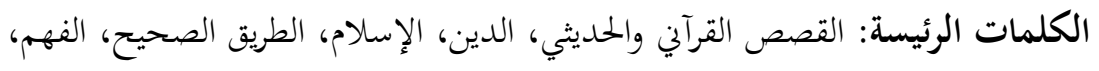

المسؤولية، المولد النبوي، البدعة، الضلال، وجهات النظر الراديكالية. 